\title{
Clinical findings of the phakomatoses von Hippel-Lindau disease
}

\author{
Mark Quigg, MD, MSc; Robert S. Rust; and James Q. Miller, MD
}
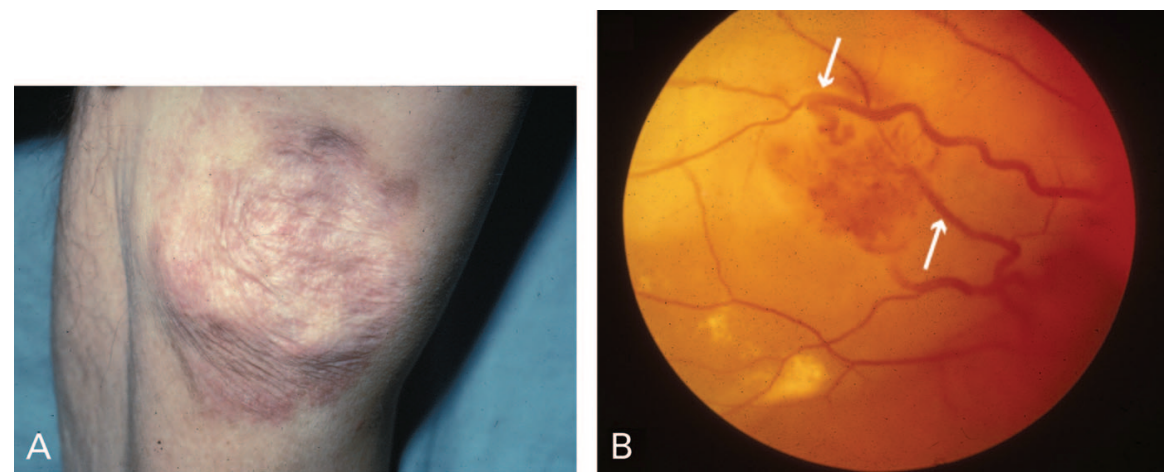

Figure 1. (A) A vascular nevus, often broad, purpuric, or even ecchymotic lesions, on the left knee of an adult with von Hippel-Lindau (VHL) disease. Unlike the other phakomatoses, skin lesions in VHL are relatively uncommon. (B) Hemangioblastoma (or angiomata) of the retina from another affected adult. Note the single dilated feeding and single draining vessel (arrows). Hemangioblastomas affect just under $60 \%$ of subjects. ${ }^{2}$ About half evolve to cause unilateral or bilateral blindness from subretinal edema, hemorrhage, or retinal detachment. ${ }^{2}$ Between $38 \%$ and $58 \%$ of individuals with retinal hemangioblastomas have VHL. VHL may also be associated with benign cysts or cystic tumors of the kidney, lung, spleen, or other abdominal organs. Malignant hypernephroma, the third most common tumor in VHL, affects $25 \%$ of subjects and is the leading cause of death. Pheochromocytoma is a less common complication (about 3-20\%). ${ }^{2}$ Risk can be determined by mutation type.

von Hippel-Lindau (VHL) disease is an autosomally dominant, pleomorphic disease of multisystem tumors. Heterogeneous germline mutations of the VHL gene (3p2526), usually arising de novo, are found in $70 \%$ to $80 \%$ of individuals. Reviews of current genetic diagnosis, screening, and pathogenesis are available. ${ }^{1}$ Physical findings are shown in figure 1 and neuroimaging findings in figure 2 .
1. Cohen D, Zhou M. Molecular genetics of familial renal cell carcinoma syndromes. Clin Lab Med 2005;25:259-277.

2. Lamiell JM, Salazar FG, Hsia YE. von Hippel-Lindau disease affecting 43 members of a single kindred. Medicine (Baltimore) 1989;68:1-29.

From the Department of Neurology, University of Virginia, Charlottesville.

Disclosure: The authors report no conflicts of interest.

Address correspondence and reprint requests to Dr. Mark Quigg, Department of Neurology, Box 800394, Health Sciences Center, University of Virginia, Charlottesville, VA 22908; e-mail: Quigg@virginia.edu 

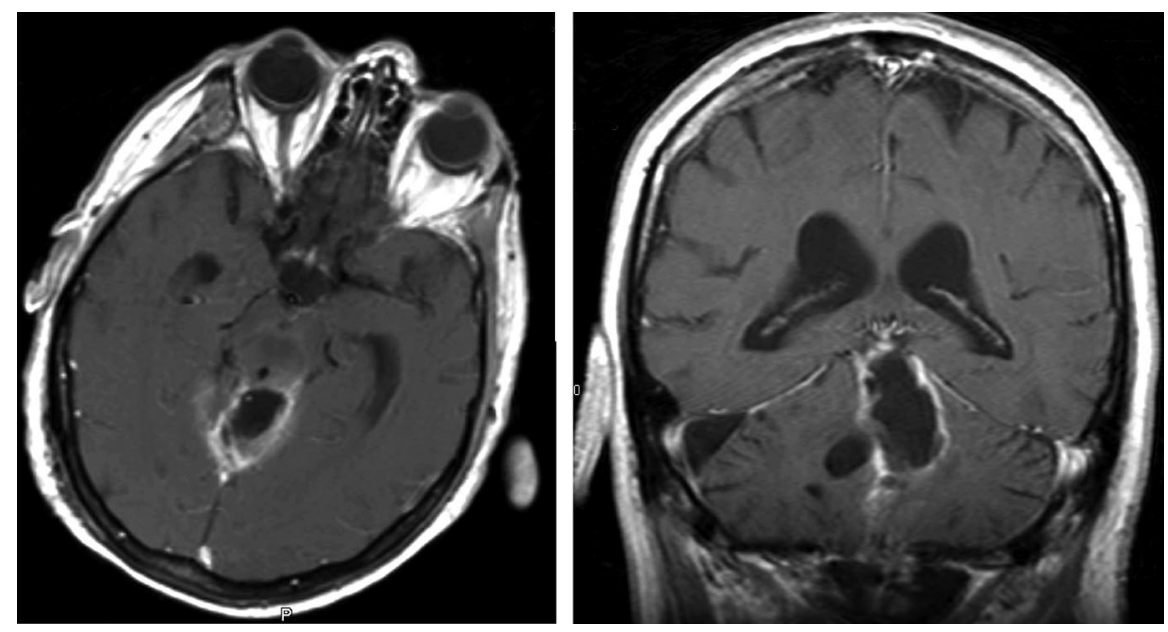

Figure 2. Cerebellar hemangioblastoma in axial and coronal sections of a contrasted T1-weighted MRI. These are present in $60 \%$ of cases in well-studied kindreds. ${ }^{2}$ About $20 \%$ of those with retinal hemangioblastoma will have a symptomatic cerebellar lesion. Cerebellar hemangioblastoma may result in devastating hemorrhage. 


\section{Neurology}

\section{Clinical findings of the phakomatoses: von Hippel-Lindau disease \\ Mark Quigg, Robert S. Rust and James Q. Miller \\ Neurology 2006;66;E33-E34 \\ DOI 10.1212/01.wnl.0000210491.21411.25}

\section{This information is current as of May 8, 2006}

Updated Information \&

Services

References

Subspecialty Collections

Permissions \& Licensing

Reprints including high resolution figures, can be found at:

http://n.neurology.org/content/66/9/E33.full

This article cites 2 articles, 0 of which you can access for free at: http://n.neurology.org/content/66/9/E33.full\#ref-list-1

This article, along with others on similar topics, appears in the following collection(s):

Arteriovenous malformation

http://n.neurology.org/cgi/collection/arteriovenous_malformation MRI

http://n.neurology.org/cgi/collection/mri

Other neurocutaneous disorders

http://n.neurology.org/cgi/collection/other_neurocutaneous_disorders

Information about reproducing this article in parts (figures,tables) or in its entirety can be found online at:

http://www.neurology.org/about/about_the_journal\#permissions

Information about ordering reprints can be found online:

http://n.neurology.org/subscribers/advertise

Neurology ${ }^{\circledR}$ is the official journal of the American Academy of Neurology. Published continuously since 1951, it is now a weekly with 48 issues per year. Copyright . All rights reserved. Print ISSN: 0028-3878. Online ISSN: 1526-632X.

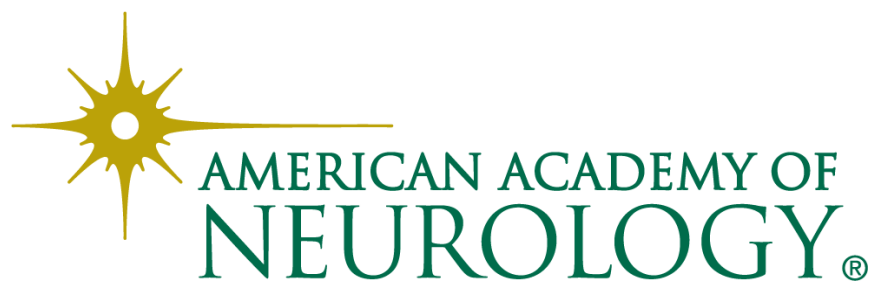

